\title{
O SINCRETISMO RELIGIOSO NO ROMANCE GREGO DE AVENTURAS OS EFÉSIOS
}

\author{
Elisa Costa Brandão de Carvalho* \\ (Universidade do Estado do Rio de Janeiro)
}

\begin{abstract}
RESUMO: a presença da religiosidade é uma das características mais marcantes do romance grego de aventuras Os Efésios, de Xenofonte de Éfeso. Com efeito, o sincretismo, próprio da cultura de então, perpassa toda a narrativa. Determinadas divindades, - Eros, Ártemis, Apolo, Hera, Ísis, Ápis, Hélio, o Nilo-, desempenham um papel ativo na trama do romance. Assim sendo, o presente trabalho tem o propósito de apresentar essas divindades, suas principais características e como se inter-relacionam dentro do romance Os Efésios.
\end{abstract}

Palavras-Chave: romance; sincretismo; Eros; Ártemis; Apolo; Hera; Hélio; Ísis; Ápis; Nilo.

\section{RELIGIOUS SYNCRETISM IN THE GREEK ADVENTURE NOVEL THE EPHESIANS}

\begin{abstract}
Greek adventure novel The Ephesians, by Xenophon of Ephesus. In effect, syncretism, typical of the culture of that time, permeates the entire narrative. Certain deities, - Eros, Artemis, Apollo, Hera, Isis, Apis, Helium, the Nile-, play an active role in the plot of the novel. Therefore, the present work has the purpose of presenting these divinities, their main characteristics and how they are interrelated within the novel The Ephesians. KEYWORDS: Novel, syncretism, Eros, Artemis, Apollo, Hera, Helium, Isis, Apis and the Nile
\end{abstract}

Qualquer sociedade, num estágio mínimo de desenvolvimento, não deixa de interagir com outros grupos, e o contato com as diversas culturas, propicia, não apenas a nível interno, mas também externo, a assimilação, por parte do grupo, de variados costumes e modos de pensar. Assim sendo, o cenário religioso chega a um momento de "estagnação", de "engessamento", demandando, então, tempos de mudança, e ensejando assim novas crenças, ideias religiosas e, concomitantemente, novos sincretismos. Desta forma o sincretismo cultural, característico das sociedades em processo de maior ou menor expansão, é resultante do constante intercâmbio do comércio humano.

\footnotetext{
*E-mail: elcbrandao@yahoo.com.br
} 
As culturas mais avançadas surgem assim, e se desenvolvem, formando a sua identidade étnica e cultural, de maneiras diversas, sem deixar de assimilar as influências econômicas, políticas e culturais - particularmente religiosas, resultantes do contato com sociedades diferentes, e tendo de "crescer junto" e aprender com seus contrastes. Considerando-se os deuses genuinamente gregos, em seus mais diversos aspectos, constata-se, de imediato, a influência, ou mesmo a assimilação, não raro desde a origem, de aspectos e características de divindades não helênicas.

Assim, diante do ecúmeno greco-romano, em sua ampla formação social abrangendo diversas etnias e levando-se em consideração o sincretismo religioso em que vários cultos convivem uns com os outros e exercem influências recíprocas, apresentaremos como ele aparece em Os Efésios, abordando, particularmente, a presença das seguintes divindades: Eros, Ártemis, Apolo, Hera, Hélio, Ísis, Ápis e o Nilo.

\section{Eros}

Eros é conhecido como o deus do amor. O nome Éros significa "desejo sensual”, e está semanticamente associado ao verbo era - "estar inflamado de amor".

As faces de Eros são muitas. Os variados mitos, no entanto, desde os tempos arcaicos da Hélade até a época helenística (do séc. IX a.C. ao séc. VI) o apresentam como elo de ligação entre os seres. Eros aparece assim como a força fundamental do mundo, e essa característica do deus marcará indelevelmente o pensamento grego em todas as suas realizações.

Podemos afirmar que Eros, o Amor, é uma espécie de fio condutor que movimenta a trama do relato amoroso (erotiká - adjetivo utilizado para qualificar os relatos amorosos característicos dos romances gregos, significa "o que tem relação com Eros", ou seja, "eróticos".), onde a týkhe (palavra derivada do verbo tugkhánein, significa "o que acontece") é onipresente.

Ao tratar dos relatos amorosos de viagem, BRANDÃO (2005, p. 235), aborda a questão da relação entre Éros e týkhe:

o que esses romances têm de específico é a presença do elemento erótico não apenas como um dos aspectos de conteúdo, mas como uma função narrativa. $\mathrm{O}$ Eros exerce neles, de fato, uma função comparada à da týkhe, enquanto o fio a partir do qual se constitui a lógica do relato.

Sendo o Amor associado à aventura, não há paradoxo maior do que o Amor, ressalta ainda BRANDÂO (ibidem, p. 236), acrescentando que, nas narrativas amorosas, a týkhe não é buscada, mas sofrida,

\footnotetext{
de certo modo, o amor é a týkhe por excelência que se representa nesse tipo de romance, e o amor não se busca, o amor acontece... É nesse sentido que o amor é um páthos que os protagonistas contraem por acaso, da mesma forma como se contrai uma doença, sendo seus primeiros sintomas percebidos efetivamente como enfermidade em [Os Efésios].
}

\section{Ártemis}

Ártemis, filha de Zeus e de Leto, é a irmã de Apolo. Com o arco, que ela recebeu do pai, juntamente com as flechas, Ártemis torna-se a deusa da caça. Como sustenta OTTO (2005, p. 71), a deusa Ártemis, associada a liberdade feminina, se espelha na natureza virginal, "com seu esplendor e sua selvageria, sua pureza sem culpa e sua 
insólita estranheza. [Ártemis] é maternal e delicadamente solícita, mas à maneira de uma autêntica virgem, ao mesmo tempo pudica, dura e cruel".

Ártemis é, ainda, considerada "a casta" (ágne). A deusa protege, por conseguinte, a castidade dos jovens. Também vinculado à lua, o culto de Ártemis pode ter sido associado a outros cultos do Mediterrâneo Oriental, particularmente o da deusa egípcia Ísis.

\begin{abstract}
Ártemis era a deusa da vida selvagem, uma virgem caçadora, acompanhada por um séquito de ninfas, e também uma deusa do parto e de todas as criaturas muito jovens. Identificava-se também essa deusa com a lua. Um centro famoso de seu culto era Éfeso, onde se destacava seu caráter maternal, e onde ela pode ter sido originariamente uma deusa asiática da fertilidade. (HARVEY, p. 61).
\end{abstract}

\title{
Apolo
}

Apolo é o deus do calor solar e da beleza. É filho de Zeus e de Leto, e irmão de Ártemis. Associado à música e à poesia. Está associado a vários oráculos, dos quais o mais importante é o de Delfos. Dirige ainda a dança e o coro das Musas. Apolo é o brilhante, o luminoso, o deus do calor solar, que faz germinar e morrer os frutos. O seu poder é terrível, tal qual o do Sol. Apolo é o conhecedor, santo, puro e luminoso (phoîbos).

Como destaca BRANDÃO (2005, p. 235), comentando a presença do elemento erótico, não só como um dos aspectos do conteúdo, mas também como uma função narrativa, acrescenta:

\footnotetext{
Não deve, portanto, causar estranheza que, mesmo alertados pelo oráculo, os pais de Antia e Habrócomes os enviaram em viagem, para mitigar as predições, mas também, ao mesmo tempo, para que pudessem, como Ulisses, "ver outras terras e outras cidades".
}

\section{Hera}

Filha de Cronos e de Reia, Hera é irmã e esposa de Zeus. Hera protege o casamento e as mulheres casadas. A sua filha, Ilítia, auxilia as mulheres no parto. Ciumenta, Hera vinga-se das conquistas amorosas de Zeus. Na Ilíada, era a protetora de Aquiles e, se posicionou contra os troianos, para se vingar de Paris. E também os Argonautas. O seu culto era dos mais difundidos na antiga Grécia.

Deusa protetora do casamento, Hera é também cultuada pelos jovens amantes, Habrócomes e Antia, como evidencia o excerto a seguir: "E naquele dia lhes soprou um vento favorável, e eles navegaram rapidamente até Samos, a ilha sagrada de Hera. Ali então, realizaram os sacrifícios, cearam e fizeram muitas preces, e quando a noite chegou, partiram novamente." (Livro I. 11. 2).

\section{Hélio}

Hélio é o deus grego do Sol. Filho de Hipério e Teia, ele tem por irmãs Aurora e Selene (a Lua). Hélio uniu-se à Oceânida Perseida, com quem teve Eetes, Circe e Pasífae. Com Climene, Hélio tem oito filhos: as sete Helíades e Faetes. Dedicado servidor de Zeus, Hélio percorre os céus diuturnamente: depois da aurora, ele aparece todas as manhãs, a Oriente, num carro de fogo, puxado por quatro cavalos luminosos; percorre o céu; e chega, ao cair da noite, ao Oceano; durante a noite, ele atravessa, num barco, o Oceano que rodeia o mundo. O culto oficial do Sol surgiu bastante tarde, desempenhando uma função muito importante no chamado paganismo tardio, e 
tendendo, gradativamente, a uma espécie de monoteísmo solar. Hélio não deve ser confundido com Apolo, embora este também seja associado ao Sol.

A heliolatria helenística é característica de uma época em que o próprio imperador romano adora o Sol (o Imperador Aureliano, 270 - 275, chegara a erguer um templo ao "Sol Invencível"). Em Os Efésios, Habrócomes é protegido pelo deus Hélio. Nesse sentido, o autor de $O s$ Efésios, acentua o espírito religioso da obra.

O excerto abaixo exemplifica a importância do deus Hélio para os jovens amantes, na narrativa de $O s$ Efésios, não faltando o típico reconhecimento dos relatos amorosos, no templo dedicado ao deus, na ilha de Rodes:

\footnotetext{
E eles [Habrócomes e Antia] visitaram toda a cidade, onde dedicaram ao templo de Hélio uma armadura de ouro e nela inscreveram um epigrama, para que fossem sempre lembrados:

Os estrangeiros, a ti, essas armas cinzeladas a ouro, dedicaram,

Os famosos Antía e Habrócomes, cidadãos da sagrada Éfeso. (Livro I. 13.2)
}

\section{Ísis}

Ísis é a deusa mais popular dentre as deusas egípcias. O seu culto acabou por se difundir por várias outras regiões. Deusa mãe, irmã e esposa de Osíris, Ísis desempenhou um papel crucial na ressurreição do esposo, assassinado por Seth, ao recolher, após muitas provações, o corpo do amado. Ísis é o tipo de esposa fiel, mesmo depos da morte. Mãe de Hórus, ela é também modelo de mãe devotada.

$\mathrm{Na}$ época do Baixo Egito, Ísis é adorada em vários lugares do país dos faraós, sobressaindo a ilha de File, onde se ergueu o seu mais famoso e duradouro santuário. Mas não se pode afirmar com certeza que esse é o lugar de seu nascimento. E no período helenístico dos Ptolomeus e dos Romanos, a crença em Ísis se irradia, do Egito, pelo mundo globalizado do ecúmeno. Assim sendo, em sua honra, dedicam-se templos, festas, ritos de mistérios, alcançando Ísis o status de uma deusa universal.

Mendoza (1979, p. 224-5) também defende a existência de um sincretismo entre os cultos de Ísis e de Ártemis, em Os Efésios, sustentando que toda a narrativa é perpassada de intenção religiosa. Com efeito, a trama do relato amoroso tem lugar e se desenvolve na vasta região do Mediterrâneo Oriental, onde a religiosidade, particularmente o culto de Îsis, desempenha um papel fundamental. E prossegue:

A deusa grega, Ártemis, e a deusa egípcia, Ísis, associadas à Lua, poderiam ser, assim, consideradas, em Os Efésios, como duas faces de uma única divindade. Desse modo, sugere ainda Mendoza (1979), Antia, provavelmente uma sacerdotisa efésia da deusa Ártemis, em seu longo périplo tortuoso, se depara com variadas cidades, conhecidas na antiguidade como centros famosos de adoração a Ísis: Rodes, Tarso, Alexandria e Mênfis.

\section{Ápis}

Dentre os animais aos quais os egípcios prestavam culto, o mais famoso era o boi Ápis. O seu culto era muito antigo, possivelmente remontando aos primeiros faraós, e o seu templo maior ficava em Mênfis. Do Egito, o culto de Ápis difundiu- se por todo o Mediterrâneo.

O boi era um símbolo de fertilidade importante, e também estava associado ao deus Sol. Do Novo Império em diante, o boi Ápis foi associado ao deus Ptah, e como o seu $b a$ (alma magnífica), era adorado em Mênfis, próxima de Saqqara, onde se edificou um cemitério para os bois Ápis. A partir da XXVI Dinastia, assistimos a um renascimento do culto de Ápis, centralizado em torno dos oráculos. Ápis também foi associado a Osíris. E o deus Serápis, fusão de Ápis e Zeus, passou a ser promovido com 
a Dinastia Lágida dos Ptolomeus, transferindo-se o seu culto para a cidade de Alexandria. O culto de Ápis e Serápis perdurou até ser proibido por um decreto do imperador Teodósio, em 380.

Segue-se o excerto abaixo, quando Antia se dirige ao templo de Ápis no Egito, e fica sabendo, por um oráculo, que pode vir a reencontrar Habrócomes dentro de pouco tempo:

\begin{abstract}
Antia foi ao templo de Ápis, o deus mais famoso do Egito, e que ali fazia profecias aos consulentes. 9- Quem quisesse, chegava diante do templo, orava e suplicava ao deus, e então umas crianças egípcias, em frente ao templo, prediziam cada uma das coisas que estavam por vir, em prosa ou em verso.
\end{abstract}

\title{
O Nilo
}

Hapi, o deus do Nilo, estava primordialmente associado às suas cheias, tão fundamentais para a própria existência do Egito. Os egípcios sempre cultuaram o rio Nilo como uma grande fonte de vida. Afinal de contas, o Egito é uma "dádiva do Nilo".

Em seu estudo da obra de Eurípides, como precursor do romance grego, SILVA (2011, p. 11) ressalta a importância do rio Nilo como um lugar exótico, profundamente marcante na imaginação dos antigos helenos: "No teatro, como mais tarde na novela, o desenho desse lugar exótico é feito com traços breves, mas expressivos. A audiência é alertada, na Helena [de Eurípides], para este objetivo inovador desde a primeira palavra da peça, Neílou 'do Nilo', de que se referem as belas correntes e a vitalidade de um Egito que o rio fertiliza à falta de chuva (v. 1-3, 89, 462). O Nilo funciona no imaginário grego como o logotipo essencial no país dos faraós".

No romance, há dois milagres que salvaram Habrócomes, às margens do grande rio do Egito. Os estudiosos consultados se dividem, ora considerando que o jovem foi salvo pelo deus Hélio nas duas oportunidades, ora atribuindo ao deus Nilo essa salvação. Levando-se em consideração que, quando estava para ser crucificado, "olhando fixamente para o sol, e vendo a correnteza do Nilo", Habrócomes rezou para que o deus o salvasse, e o deus se apiedou dele e o salvou, e que, quando estava para ser queimado às margens do Nilo, o jovem "rezou de novo, e o Nilo agitou-se, e um vagalhão se abateu sobre a pira, fazendo extinguir as chamas", considera-se aqui a possibilidade de, em meio ao sincretismo religioso da época, o deus Hélio ter salvado o seu devoto, com a ajuda providencial do deus Nilo.

Nesse sentido, a história dos grandes impérios e civilizações propicia múltiplas "globalizações" ao longo dos tempos, num processo não linear de formação de identidades culturais, através de trocas, assimilações e desafios sempre instigantes, ficando evidente no romance a intenção religiosa, numa época caracterizada pelo sincretismo, com a expansão dos cultos de Ísis e de Ápis, e a identificação da deusa Ísis com algumas divindades gregas.

\section{Referências bibliográficas}

BAILLY, A.. Dictionnaire Grec-Français. Paris: Hachette, 1979.

BAKHTIN, Mikhail. Questões de Literatura e Estética: A Teoria do Romance. Tradução: Aurora Fornini Bernardini et alii. São Paulo: Editora Unesp, 1993. 
BRANDÃO, Jacyntho Lins. A invenção do romance. Brasília: Editora Universidade de Brasília, 2005 (Coleção Pérgamo).

CALAME, Claude. Eros na Grécia Antiga. Tradução de Isa Etel Kopelman. São Paulo: Perspectiva, 2013.

ÉFESO, Jenofonte. Efesíacas. Trad. Julia Mendoza. Madrid, Editorial Gredos S. A., 1979.

ÉPHÈSE, Xénophon. Les Éphésiaques ou Le Roman d'Habrocomés et d'Anthia. Trad.

Georges Dalmeyda. Paris, Les Belles Lettres, 1962. $2^{\mathrm{a}}$ ed.

GRIMAL, Pierre. Dictionnaire de la mythologie grecque et romaine. Paris, PUF, 1982.

HARVEY, Paul. Dicionário Oxford de Literatura Clássica: Grega Latina. Tradução: Mário da Gama Kury. Rio de Janeiro, Jorge Zahar Editor, 1998.

HESÍODO. Teogonia. Estudo e trad. Por Jaa Torrano. São Paulo: Iluminuras, 2006.

OTTO, Walter Friedrich. Os deuses da Grécia: a imagem do divino na visão do espírito grego. Tradução [e prefácio] de Ordep Serra. São Paulo: Odysseus Editora, 2005.

POSENER, Georges. Dictionnaire de la civilisation égyptienne. Paris, Fernand Hazan, 1992.

SILVA, M. F. Eurípedes, um Precusor do Romance Grego. IN: Calíope: presença clássica/Programa de Pós-Graduação em Letras Clássicas, Departamento de Letras da Universidade Federal do Rio de Janeiro, vol. 21, 2011.

VERNANT, Jean-Pierre. O Homem Grego. Direção: Jean Pierre Vernant. Lisboa. Editorial Presnça.,1991. , Jean-Pierre. As origens do pensamento grego. São Paulo, Difel, 1984. Jean-Pierre. Mito e pensamento entre os gregos. Trad. Haiganuch Sarian Rio de Janeiro: Ed. Paz e Terra, 2008.

WHITMARSH, Tim. Narrative and Identity in the Ancient Greek Novel: Returning Romance. UK, Cambridge University Press, 2011, $1^{\text {a }}$ ed. 